\title{
CRITERIAL CONDITIONS FOR OPTIMIZATION \\ OF THE STRUCTURE OF CAPITAL OF ENTERPRISE
}

\section{КРИТЕРІАЛЬНІ УМОВИ ОПТИМІЗАЦЇ̈ СТРУКТУРИ КАПІТАЛУ ПІДПРИЕМСТВА}

\author{
Kvasnitska Raisa ${ }^{1}$ \\ Starostenko Ganna ${ }^{2}$
}

DOI: dx.doi.org/10.30525/978-9934-571-30-5_22

\begin{abstract}
Provision of enterprises with sufficient volume of financial and property funds is a guarantee of efficient conduct of their economic activity. Under these conditions, one of the main tasks of creating favorable financial and property fundamentals of the continuity of the reproductive process of economic entities, and hence of the national economy of the country, is the solution of issues of improving the approaches to the formation of an optimal of structure of capital of enterprises. The purpose of the article is to substantiate theoretical principles and methodological approaches to managing the target of structure of capital of enterprises of various sectors of the economy of Ukraine for its optimization, which will ensure the financial stability of the functioning of enterprises in modern economic conditions. The object of research is the process of managing the formation of structure of capital of enterprises. The subject of the research is the theoretical and methodological principles of management of the target of structure of capital of enterprises with the aim of its optimization in order to ensure financial stability of efficient functioning of enterprises in modern economic conditions. Results. The novelty of the research is to develop a new approach to managing the formation of the optimal target of structure of capital of enterprises by the method of the combined effect of increasing the return on equity and ensuring the adequacy of the level
\end{abstract}

\footnotetext{
${ }^{1}$ Doctor of Economic Sciences,

Professor of the Department of Finance, Banking and Insurance,

Khmelnitsky National University, Ukraine

${ }^{2}$ Doctor of Economic Sciences,

Professor of the Department of Economic Theory,

National University of the State Fiscal Service of Ukraine, Ukraine

(C) Kvasnitska Raisa, Starostenko Ganna
} 


\section{Berezianko Tamara}

of financial stability, which allows practically to determine the predicted relationships between elements of the property and financial structure of capital, which ensure the financially stable development of the enterprise in the perspective. Conclusion. The theoretical and applied significance of the conducted research is determined by the fact that the conclusions and recommendations set forth in the article will serve as the basis for new opportunities for improving the financial security of enterprises in various sectors of the economy.

\section{1. Вступ}

Побудова в Україні ринкових економічних відносин потребує принципово нових підходів до вирішення проблеми достатності фінансово-майнового забезпечення функціонування суб'єктів господарювання. Адже, саме забезпеченість підприємств оптимальною кількістю фінансово-майнових засобів і $є$ запорукою ефективного ведення ними господарської діяльності, основою фундаменту економічної стабільності країни в цілому. За цих умов одним із основних завдань створення сприятливих фінансово-майнових засад безперервності відтворювального процесу суб'єктів господарювання, а отже і національної економіки, $є$ вирішення питань удосконалення підходів до оптимізації структури капіталу підприємств.

Хоча формування різноелементного складу (структури) капіталу підприємства $є$ його індивідуальною прерогативою, все ж воно не завжди є економічно обгрунтованим з позицій узгодженості отримання на підприємстві одночасного зростання рентабельності власного капіталу та забезпечення фінансової стійкості. Вирішення питань підвищення ефективності прийняття управлінських рішень щодо структуризації капіталу потребує теоретичного переосмислення понять «капітал підприємства» та «структура капіталу підприємства», аналізу чинників формування певної структурної будови капіталу та практичної розробки оптимальної структури капіталу за певними цільовими критеріями її оптимальності.

В Україні відчувається значний дефіцит досліджень, орієнтованих на пошук управлінських заходів щодо оптимізації структури капіталу за цільовим іiї спрямування згідно критеріальної відповідності потребам конкретного підприємства. Розробка та впровадження ефективних методів формування оптимальної цільової структури капіталу підпри- 
ємств дає можливість підвищення результативності прийняття управлінських рішень, орієнтованих на забезпечення фінансово стійкого та прибуткового функціонування більшості підприємств.

Метою дослідження є обгрунтування теоретичних засад і методичних підходів до управління цільовою структурою капіталу підприємств різних галузей економіки України для ії оптимізації, що дозволить забезпечити фінансову стабільність функціонування підприємств в сучасних умовах господарювання. Для досягнення поставленої мети були поставлені та розв'язані такі завдання: удосконалити алгоритм розрахунків складових ефекту фінансового важеля, а саме економічної рентабельності активів підприємства та середньої розрахункової відсоткової ставки за кредитні ресурси; надати пропозиції щодо вдосконалення критеріального інструментарію формування оптимальної цільової структури капіталу за умови забезпечення фінансово стійкого розвитку підприємства.

Об'єктом дослідження є процес управління формуванням структури капіталу підприємств. Предметом дослідження є теоретичні та методичні засади управління цільовою структурою капіталу підприємств з метою її оптимізації для забезпечення фінансової стабільності ефективного функціонування підприємств в сучасних умовах господарювання.

В процесі дослідження залежно від конкретних цілей та завдань використовувались відповідні загальні методи (аналіз, синтез та системний підхід щодо з'ясування внутрішньої суті та природи об'єкта дослідження, вивчення його деталізації та залежності від різноманітних факторів) та методи економічного аналізу (метод статистики та математичного моделювання щодо визначення варіантів оптимізації цільової структури капіталу промислових підприємств).

Новизна дослідження полягає у розробці нового підходу до управління формуванням оптимальної цільової структури капіталу підприємств за методом поєднаного ефекту зростання рентабельності власного капіталу та забезпечення достатності рівня фінансової стійкості, що дозволяє практично визначити прогнозні співвідношення елементів майнової та фінансової структури капіталу, які забезпечують фінансово стабільний розвиток підприємства на перспективу.

Теоретична та прикладна значущість проведеного дослідження визначається тим, що висновки та рекомендації, викладені в статті, 


\section{Berezianko Tamara}

слугуватимуть основою нових можливостей щодо підвищення ефективності фінансового забезпечення діяльності підприємств різних галузей економіки.

\section{2. Фінансовий важіль як інструмент впливу}

\section{на рентабельність капіталу підприємства}

У процесі здійснення господарської діяльності підприємство використовує такі елементи структури капіталу, як власний та запозичений капітал. Із виникненням запозичених коштів у загальній величині капіталу, що використовується підприємством, постає необхідність дослідження співвідношення власних та запозичених джерел фінансування діяльності цього підприємства, тобто прийняття управлінських рішень про певну структуру капіталу, яка дає можливість здійснення його індивідуального розширеного відтворення. Досконалість політики підприємства щодо управління структуризацією його капіталу знаходить відображення в оптимальній цільовій структурі капіталу, яка характеризується таким співвідношенням власних та запозичених коштів, при якому максимально зростає дохідність (рентабельність) власного капіталу підприємства. Як відомо, показник рентабельності власного капіталу $є$ найбільш застосовуваним показником, який оцінює ефективність використання власного капіталу підприємства. Даний показник відображає величину чистого прибутку підприємства, що припадає на одну гривню його власного капіталу. Узагальнено рентабельність власного капіталу може розглядатись за двома основними визначеннями: як економічна та як фінансова [3, с. 175]. Якщо для розрахунку рентабельності використовуються прогнозні (потенційні) значення величини прибутку, то на їх основі оцінюється економічна рентабельність власного капіталу. Якщо ж базою визначення рентабельності власного капіталу є реальний (фактичний) прибуток, який отримано за даними «Звіту про фінансові результати» (форма № 3 фінансової звітності підприємства), то отримують фінансову рентабельність власного капіталу.

Саме фінансова рентабельність $є$ основою трендових розрахунків щодо визначення економічної рентабельності. Тому, на нашу думку, досягнення максимальної економічної рентабельності власного капіталу в перспективі залежить від правильної оцінки його фінансової рентабельності за ряд попередніх звітних періодів. 


\section{Chapter 12. Economic sciences}

Необхідно зазначити, що динаміка переважної величини власного або запозиченого капіталу підприємства $є$ безпосереднім чинником впливу на рентабельність власних коштів. Адже при усіх рівних умовах щодо величини прибутку підприємств та його оподаткування рентабельність їх власного капіталу може зростати лише при збільшенні величини запозиченого капіталу.

Тому вірний вибір формування складу та розміру запозичених джерел у загальній структурі капіталу підприємства є запорукою збільшення обсягів виробництва та реалізації продукції, а отже, і росту доходів підприємства та його прибутковості в цілому. Наслідком ефективного формування запозиченого капіталу $є$ також ріст рентабельності власного капіталу без збільшення розміру самих власних коштів.

Звичайно, невірний вибір структуризації та величини запозичених джерел забезпечення діяльності підприємства може вкрай негативно відобразитися на його платоспроможності, а отже, і на фінансовій стійкості. Це пояснюється тим, що боргові зобов'язання щодо запозичених коштів мають бути погашені у визначеному порядку та у визначені строки незалежно від результатів діяльності підприємства.

Оцінити вплив використання запозиченого капіталу на рентабельність власного капіталу дозволяє фінансовий важіль, який і $є$ інструментом регулювання пропорцій структурних елементів капіталу підприємств 3 метою максимального росту рентабельності власних коштів. Термін «важіль» у економічній літературі має декілька синонімів: «левередж» (leverage) згідно трактувань американських економістів; «жирінг» (gearing) за трактуванням європейських (англійських) економістів. В ракурсі трактування терміну «важіль» як фінансового, ми бачимо, що він виступає як потенційна можливість впливу зміни питомої ваги власного та запозиченого капіталу підприємства в загальній його величині на прибутковість власних коштів. Показник фінансового важеля означає включення у структуру капіталу підприємства боргу, який дає постійний прибуток [5, с. 154].

Конкретний результат впливу фінансового важеля на рентабельність власного капіталу проявляється через ефект фінансового важеля. Саме даний показник відображає приріст рентабельності власних коштів, який отримується завдяки використанню запозичених коштів, не дивлячись на їх платність та поверненість [1, с. 126]. 


\section{Berezianko Tamara}

На сьогодні в практиці визначення ефекту фінансового важеля сформовано дві основні концепції: американська та європейська.

Згідно з першою концепцією ефект фінансового важеля визначається як динаміка чистого прибутку на акцію у відсотковому вираженні, що спричинена зміною прибутку до сплати податку на прибуток і відсотків за запозиченим капіталом.

За другою концепцією, визначення ефекту фінансового важеля здійснюється як приріст рентабельності власного капіталу за рахунок використання підприємством запозичених коштів, що потребують певних фінансових витрат щодо їх обслуговування, тобто оплати певних визначених відсотків за користування ними.

Використання трактування ефекту фінансового важеля за американською концепцією не дає можливості визначення безпечної величини й умов залучення підприємством запозичених коштів. Цю проблему дає змогу вирішити саме використання європейської концепції визначення ефекту фінансового важеля.

Необхідно зазначити, що американська концепція $є$ більш вузькою щодо іiї застосування при формуванні структури капіталу підприємств різних форм власності та різних організаційно-правових форм. Вона $€$ застосовуваною лише підприємствами колективної форми власності, в яких статутний (пайовий) капітал розділено на певні частки, що приносять їх власникам дохід у вигляді дивідендів.

Тому, на наш погляд, європейська концепція визначення ефекту фінансового важеля є більш узагальнюючою, а тому і більш застосовуваною різними суб'єктами господарювання незалежно від їх організаційно-правового статусу. Такий висновок дає нам змогу акцентувати увагу саме на цій концепції. Ї̈ї сутність та значення розкривається в роботах багатьох економістів: І.О. Бланка, М.Н. Крейніної, М.Ф. Ляліна, С.Г. Рясних, В.О. Меца, Л.О. Коваленко, Л.М. Ремньової, О.О. Терещенка, В.В. Бочарова та інших.

Розрахунок ефекту фінансового важеля (ЕФВ) більшістю вищезазначених авторів здійснюється за формулою (1):

$$
\mathrm{E} Ф В=(1-\text { СтП }) \mathrm{x}(\mathrm{EPA}-\mathrm{CPCB}) \mathrm{x} \frac{3 \mathrm{~K}}{\mathrm{BK}},
$$

де СтП - ставка податку на прибуток підприємства, десятковий дріб; 
ЕРА - економічна рентабельність активів, \%;

$\mathrm{CPCB} \mathrm{-} \mathrm{середня} \mathrm{розрахункова} \mathrm{ставка} \mathrm{відсотків} \mathrm{за} \mathrm{запозиченим} \mathrm{капі-}$ талом, \%;

ЗК - запозичений капітал (у частині кредитних запозичень), грн;

ВК - власний капітал, грн.

У даній формулі доцільно виділити окремі розрахункові елементи, які $є$ різнонаправленими щодо позитивного впливу чинниками формування загальної величини ефекту фінансового важеля.

Так, у формулі ефекту фінансового важеля виділяють два розрахункові елементи:

1) диференціал фінансового важеля, тобто різницю між рентабельністю активів та середньою ставкою відсотку за запозиченим капіталом;

2) плече фінансового важеля, тобто співвідношення запозиченого та власного капіталу підприємства.

Різнонаправленість впливу цих розрахункових елементів полягає в тому, що диференціал є основою росту ефекту фінансового важеля, а плече фінансового важеля - це інструмент посилення дії ефекту фінансового важеля. Позитивність диференціалу, що формується під впливом росту плеча фінансового важеля, є запорукою позитивної дії ефекту фінансового важеля, тобто приросту рентабельності власного капіталу підприємства.

Однак чим більше плече фінансового важеля, тим вищий фінансовий ризик підприємства щодо формування ним власної структури капіталу. Така двояка ситуація свідчить про наявність певного протиріччя між позитивним впливом плеча фінансового важеля на ріст рентабельності власного капіталу та негативними наслідками його впливу при нераціональній структурі капіталу, яка характеризується незначною часткою власних коштів та високою фінансовою залежністю за запозиченим капіталом. Тому ефект фінансового важеля можна розглядати не тільки як інструмент максимізації рентабельності власного капіталу на основі регулювання пропорцій власного та запозиченого капіталу, а й як вимірник рівня фінансового ризику підприємства.

3 вищевикладеного можемо зробити висновок про необхідність дослідження питання економічно обгрунтованої правильності визначення самого ефекту фінансового важеля. 


\section{3. Обгрунтування правильності розрахунку \\ ефекту фінансового важеля}

Хоча поняття ефекту фінансового важеля різними авторами й розглядається в однаковому аспекті показника, що відображає приріст рентабельності власного капіталу за рахунок використання запозичених коштів, існують і певні розбіжності у визначенні розрахункових елементів цього показника. Ці розбіжності призводять до суттєвих похибок в отриманні кінцевого результату розрахунку, а отже, і в оцінці рівня раціональності співвідношення власного та запозиченого капіталу підприємства.

Так, суттєвими за своїм змістом є розбіжності визначень даних щодо розрахунку диференціалу фінансового важеля, а саме економічної рентабельності активів, яка виступає життєво важливий показник для підприємства, адже іiі достатній рівень $є$ свідченням теперішніх та запорукою майбутніх успіхів підприємства. Тому, ми можемо погодитись із тими авторами $[7 ; 8 ; 9]$, які при розрахунку економічної рентабельності використовують такий показник, як нетто-результат експлуатації інвестицій. Адже саме цей показник найбільш змістовно відображає економічний ефект, який отримує підприємство за рахунок залучення запозичених кредитних ресурсів.

Нетто-результат експлуатації інвестицій розраховується як сума прибутку підприємства від операційної діяльності (основної діяльності підприємства, тобто операцій, пов'язаних із виробництвом та реалізацією продукції (товарів, робіт, послуг), що є головною метою створення підприємства, і забезпечують основну частину його доходу та суми відсотків за кредитні ресурси підприємства. Таким чином, даний показник розраховується за такою формулою:

$$
\text { HPEI }=\text { Попр }+ \text { Вкр , }
$$

де, НРЕІ - нетто-результат експлуатації інвестицій;

П опр - прибуток від операційної діяльності підприємства;

В кр - сума відсотків за залучені підприємством кредити.

Тому розрахунок економічної рентабельності активів необхідно здійснювати за формулою:

$$
\mathrm{EPA}=\frac{\mathrm{HPEI}}{\mathrm{A}},
$$

де А - обсяг активів підприємства. 
На нашу думку, уточнення розрахунку вимагає такий розрахунковий елемент економічної рентабельності активів. як обсяг активів підприємства. Так, використання при обчислені економічної рентабельності активів, значень обсягу активів підприємства на початок чи на кінець звітного періоду не $є$ достатньо інформативним щодо отримання фактичного значення шуканого нами показника. Тому обсяг активів підприємства необхідно визначати як середню величину звітного періоду.

Будь-яка середня величина характеризує типовий рівень варіюючої ознаки. Для обчислення середньої величини використовують різні формули, які відповідають певним видам середніх:

1) аналітичні середні: арифметична (проста та зважена); гармонійна (проста та зважена); хронологічна, геометрична;

2) структурні середні: мода та медіана.

Як відомо, середні величини в статистиці належать до класу степеневих середніх, які описує узагальнена формула [4, с. 93]:

$$
\bar{X}=\sqrt[m]{\frac{\sum X^{m}}{n}}
$$

де, $\mathrm{X}$ - рівень ознаки або варіант;

$\mathrm{n}$ - число варіантів;

$\mathrm{m}$ - показник степеня середньої.

Зміна степеня середньої визначає ії вигляд: $\mathrm{m}=1$ - середня арифметична; $\mathrm{m}=0$ - середня геометрична; $\mathrm{m}=-1$ - середня гармонійна; $\mathrm{m}=2$ - середня квадратична; $\mathrm{m}=3$ - середня кубічна.

Для визначення варіативності зміни значень середньої вартості активів підприємства можна використати підрахунок середньої вартості активів підприємства за середньою квадратичною, оскільки даний показник $\epsilon$ найбільш використаним із степеневих середніх у статистиці саме для розрахунку варіації. Середню квадратичну вартості активів підприємства можна подати у вигляді формули:

$$
\overline{\mathrm{A}}=\sqrt{\frac{\sum \mathrm{a}_{\mathrm{i}}^{2}}{\mathrm{~T}}}, \mathrm{i}=\overline{1, \mathrm{~T}},
$$

де $\mathrm{a}_{\mathrm{i}}$ - значення вартості активів на кінець звітного місяця (року);

т - кількість місяців (років), за які проводиться спостереження.

Однак, на нашу думку, використання даної формули для визначення середньої вартості активів підприємства має недолік щодо врахування характеристики вартості активів за певні періоди часу, а не на певний 


\section{Berezianko Tamara}

момент часу. Адже вартість активів підприємства, що формує середню ïx величину, не $\epsilon$ накопичуваним показником, а $\epsilon$ узагальнюючою характеристикою вартості активів на певний момент часу. Тому, ми вважаємо, що вартість активів підприємства має бути систематизована відповідно до вираження динаміки показників у часі за рядами динаміки. Тобто помоментна вартість активів (їх вартість у певному звітному періоді) має бути сформована у моментний динамічний ряд. Саме на основі побудованого моментного динамічного ряду вартості активів підприємства уможливлюється розрахунок середньої вартості активів за середнім рівнем динамічного ряду, який є більш ефективним щодо економічної доцільності подальшого використання даного показника.

Для обчислення середнього рівня моментного динамічного ряду використовують формулу середньої хронологічної. Підставивши вартість активів підприємства на кінець і-того періоду, у розрахунок середньої, ми отримуємо формулу визначення середньої вартості активів підприємства звітного періоду :

$$
\overline{\mathrm{A}}=\frac{\frac{1}{2} \mathrm{a}_{1}+\mathrm{a}_{2}+\ldots+\mathrm{a}_{\mathrm{n}-1}+\frac{1}{2} \mathrm{a}_{\mathrm{n}}}{\mathrm{n}-1},
$$

У такий спосіб розрахована середня вартість активів дає можливість оцінки економічної рентабельності активів з максимальним врахуванням фіксації моментів спостережень вартості активів, що забезпечує більш точну оцінку варіативності цієї вартості (формула 7):

$$
\text { EPA }=\frac{\text { HPEI }}{\overline{\mathrm{A}}}=\frac{\text { Попр }+ \text { Вкр }}{\left(\frac{\frac{1}{2} \mathrm{a}_{1}+\mathrm{a}_{2}+\ldots+\mathrm{a}_{\mathrm{n}-1}+\frac{1}{2} \mathrm{a}_{\mathrm{n}}}{\mathrm{n}-1}\right)}
$$

Ми підтримуємо думку О.С. Стоянової [8] про доцільність розрахунку показника середньої розрахункової ставки відсотків за запозиченим капіталом із використанням формули середньої величини, тобто із урахуванням різних кредитів та позик підприємства за певний період. Однак на відміну від середньої величини активів підприємства для визначення даного показника варто застосовувати середню арифметичну зважену, яка визначається діленням суми добутків індивідуальних значень ознаки $\left(\mathrm{x}_{i}\right)$ та їх частот $\left(\mathrm{f}_{i}\right)$ на суму частот (формула 8) [99, с. 52]: 


$$
\bar{x}=\frac{x_{1} \times f_{1}+x_{2} \times f_{2}+\ldots+x_{n} \times f_{n}}{f_{1}+f_{2}+\ldots+f_{n}}=\frac{\sum x_{i} \times f_{i}}{\sum f_{i}}
$$

Підставивши замість ознак $\left(\mathrm{x}_{i}\right)$ позначення відсоткової ставки за кредит, а замість частот $\left(\mathrm{f}_{i}\right)$ - суму окремих залучених підприємством кредитів, отримаємо нову формулу:

$$
\mathrm{CPCB}=\frac{\mathrm{BC}_{1} \times \mathrm{Kp}_{1}+\mathrm{BC}_{2} \times \mathrm{Kp}_{2}+\ldots+\mathrm{BC}_{\mathrm{n}} \times \mathrm{Kp}_{\mathrm{n}}}{\mathrm{Kp}_{1}+\mathrm{Kp}_{2}+\ldots+\mathrm{Kp}_{\mathrm{n}}}=\frac{\sum \mathrm{BC}_{\mathrm{i}} \times \mathrm{Kp}_{\mathrm{i}}}{\sum \mathrm{Kp}_{\mathrm{i}}},
$$

де ВС - відсоткова ставка конкретного кредиту, який залучено підприємством у звітному періоді;

Кр - сума конкретного кредиту, який залучено підприємством у звітному періоді.

На основі виділення певних підходів щодо визначення розрахункових елементів економічної рентабельності, диференціалу фінансового важеля (формули 7; 9) ми маємо змогу відобразити перетворену формулу розрахунку ефекту фінансового важеля:

$$
\begin{aligned}
& \mathrm{E} Ф \mathrm{~B}=\left((1-\text { СтП }) \times(\mathrm{EPA}-\mathrm{CPCB}) \times \frac{3 \mathrm{~K}}{\mathrm{BK}}=\right. \\
& \left.=(1-\text { СТП }) \times\left[\left(\frac{\mathrm{HPEI}}{\overline{\mathrm{A}}} \mathrm{x} 100\right)-\mathrm{CPCB}\right)\right] \times \frac{3 \mathrm{~K}}{\mathrm{BK}}= \\
& =(1-\text { СтП }) \times\left[\left(\frac{\text { Попр }+ \text { Вкр }}{\overline{\mathrm{A}}}\right)-\text { СРВС }\right] \times \frac{3 \mathrm{~K}}{\mathrm{BK}}= \\
& =(1-\text { СтП }) \times\left[\frac{\text { Попр }+ \text { Вкр }}{\left(\frac{\frac{1}{2} \mathrm{a}_{1}+\mathrm{a}_{2}+\ldots+\mathrm{a}_{\mathrm{n}-1}+\frac{1}{2} \mathrm{a}_{\mathrm{n}}}{\mathrm{n}-1}\right)}-\left(\frac{\sum \mathrm{BC}_{\mathrm{i}} \mathrm{x} \mathrm{K \textrm {K } _ { \mathrm { i } }}}{\sum \mathrm{Kp}_{\mathrm{i}}}\right)\right] \times \frac{3 \mathrm{~K}}{\mathrm{BK}}
\end{aligned}
$$

Дана формула більш змістовно враховує суб'єктивний та об'єктивний вплив розрахункових елементів ефекту фінансового важеля, що й забезпечує точність розрахунку рівня даного показника.

Як зазначалось вище, вплив використання запозиченого капіталу проявляється в постійному тандемі 3 фінансовим ризиком: ефект 


\section{Berezianko Tamara}

фінансового важеля може бути позитивним, до якого тяжіють підприємства, а також і негативним, якого підприємства бояться. Позитивний, постійно зростаючий ефект фінансового важеля, на перший погляд, $\epsilon$ запорукою ефективного економічного розвитку підприємства. Однак, він $\epsilon$ ще й індикатором фінансової стійкості підприємства щодо зниження його платоспроможності.

Отже, між фінансовим важелем та фінансовою стійкістю підприємства існує певне протиріччя: фінансовий важіль $є$ прирістним чинником, тобто чинником-стимулятором рентабельності власного капіталу підприємства, тобто позитивним показником раціональної структури капіталу, й одночасно регресним чинником рівня його фінансової стійкості, негативним показником платоспроможності.

Для згладжування даного протиріччя, на нашу думку, необхідне обов'язкове врахування структури капіталу підприємства за їі двояким розглядом щодо класифікаційного ранжирування капіталу за джерелами формування та конкретним майновим забезпечення функціонування підприємств. Підвищення рівня фінансової стійкості підприємства за рахунок фінансового важеля може бути можливим при умові одночасного його встановлення за співвідношенням власного та запозиченого капіталу, а також за співвідношенням грошових та негрошових активів.

Такий підхід до пошуку оптимальної цільової структури капіталу підприємства щодо іiі позитивного впливу як на рентабельність власного капіталу, так і на рівень фінансової стійкості, дасть змогу дотримання максимального позитивного рівня ефекту фінансового важеля щодо росту рентабельності власного капіталу та платоспроможності підприємства.

\section{4. Методи оптимізації структури капіталу підприсмства}

Сучасними умовами господарювання чітко виражено економічну самостійність підприємств щодо визначення розміру та структури їх капіталу. Диференційований підхід до вибору джерел фінансування діяльності підприємств дає можливість регулювати рівень їх фінансової стійкості.

Зрозуміло, що більш стійкими за фінансовим забезпеченням є підприємства, діяльність яких повністю фінансується за рахунок власних коштів. Однак, все ж не є виключенням, коли підприємства для фінан- 
сування своєї діяльності використовують і запозичені кошти. Причому, із залученням підприємствами певної частки запозиченого капіталу, виникає й можливість підвищення дохідності використовуваного ними сукупного власного капіталу. Таким чином, суб' єкти господарювання завдяки власному вибору тих чи інших джерел фінансування їх фінансово-майнового забезпечення отримують змогу регулювати як свою платоспроможність - фінансову стійкість, так і прибутковість.

Необхідно відмітити, що дилема вибору підприємством тієї чи іншої структури капіталу може бути вирішена лише за умови вибору певної критеріальної характеристики оптимальності співвідношення структурних елементів капіталу. Адже, традиційно, завдання вибору найкращих рішень здійснювалося за допомогою єдиної числової функції - критерію оптимальності. Кращим вважалося рішення, що забезпечує максимум (або мінімум) обраного критерію [10, с. 352].

При цьому зауважимо, що врахування тісного взаємозв'язку та взаємозалежності фінансової стійкості підприємства та рівня його фінансового важеля найбільш змістовно розкриває регулятивні можливості щодо пошуку оптимальності цільової структури капіталу підприємства.

Так, перш ніж окремо виділити певний метод оптимізації цільової структури капіталу, що, на нашу думку, є найбільш раціональним, звернемо увагу на те, що у теоретичному викладі, а отже, й практичному застосуванні, таких методів $є$ не багато. Так, детальний виклад можливості оптимізації структури капіталу підприємства за різними методами наведено I.О. Бланком [2, с. 214-222]. Такими методами ним виділені:

1) метод оптимізації структури капіталу за критерієм максимізації рівня прогнозованої фінансової рентабельності (рентабельності власного капіталу), який базується на багатоваріантних розрахунках рівня фінансової рентабельності (рентабельності власного капіталу) при різній структурі капіталу, що виражається через такий показник, як ефект фінансового важеля;

2) метод оптимізації структури капіталу за критерієм мінімізації його вартості, який базується на попередній оцінці власного та запозиченого капіталу при різних умовах їх формування, обслуговування та здійснення багатоваріантних розрахунків середньозваженої вартості капіталу i, таким чином, пошуку найбільш реальної ринкової вартості підприємства; 


\section{Berezianko Tamara}

3) метод оптимізації структури капіталу за критерієм мінімізації рівня фінансових ризиків, який пов'язаний з процесом диференційованого вибору джерел фінансування різних складових частин активів підприємства: необоротних активів, оборотних активів (із розбивкою їх на постійну та змінну частину).

Як бачимо, в основі кожного з вищезазначених методів лежить один конкретний критерій. Враховуючи те, що ми виділили основними критеріальними показниками оптимізації цільової структури капіталу, які максимізуються - рентабельність власного капіталу та рівень фінансової стійкості, - то зрозумілим буде наш висновок щодо необхідності виокремлення такого оптимізаційного методу, що базується саме на використанні цих критеріїв.

Тому, на нашу думку, найбільш раціональним щодо досягнення оптимальності співвідношення структурних елементів капіталу підприємства може бути метод, який базується на поєднаному ефекті одночасного росту рентабельності власного капіталу та забезпечення фінансової стійкості. Чому ми наголошуємо саме на критеріально поєднаному ефекті у виокремленому нами методі оптимізації цільової структури капіталу підприємства? Тому що, коли використовувати метод оптимізації цільової структури капіталу лише за критерієм максимізації рівня прогнозованої фінансової рентабельності, який дає можливість розрахунково знайти лише оптимальну величину ефекту фінансового важеля, то інший аспект достатності власних коштів для нормального функціонування підприємства - його платоспроможність, може бути недопустимо заниженим. Тобто оптимально великий рівень ефекту фінансового важеля визначає ріст рентабельності власного капіталу i, в той же час, як правило, призводить і до погіршення фінансового стану підприємства, а саме, до порушення умов платоспроможності та, як наслідок, до нестачі власних грошових коштів.

Щоб фінансовий важіль справляв одночасний позитивний ефект і на рентабельність власного капіталу, і на фінансову стійкість, необхідним є визначення ефективного співвідношення між миттєво ліквідним та іншим майновим забезпеченням зобов'язань підприємства. Тобто потрібен розрахунок рівня фінансового важеля не тільки в структурі джерел фінансування майна підприємства (тобто у фінансовій структурі капіталу), а й у структурі активів (майновій структурі підприємства) (рис. 1). 
Отже, лише комплексність розгляду ранжирування капіталу підприємства за джерелами фінансування діяльності та конкретним його майновим втіленням дає можливість оперативного та перспективного регулювання рівня фінансової стійкості підприємства.

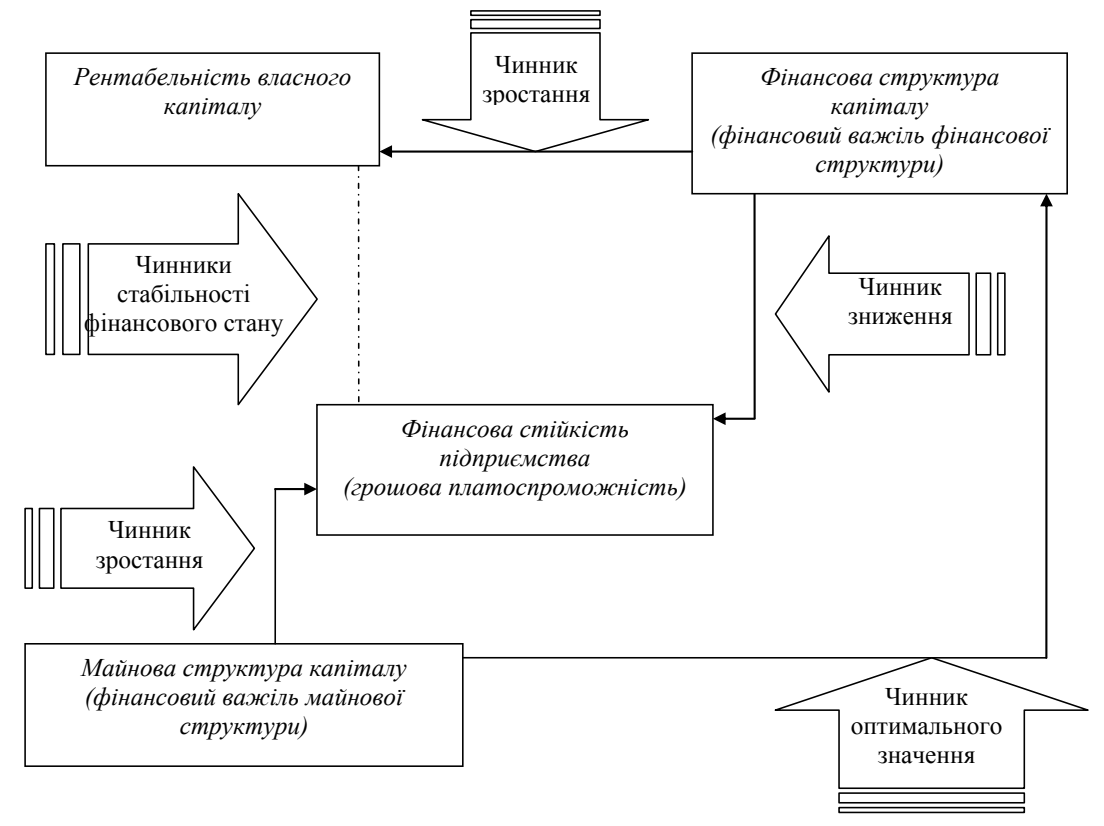

\section{Рис. 1. Взасмозв'язок і взасмозалежність фінансових важелів структуризації капіталу як чинників зміни рівня фінансової стійкості підприємства}

Знаючи майнові напрямки використання капіталу підприємства за їх грошовою та не грошовою формою, можна регулятивно корегувати досягнення платоспроможності підприємства саме в грошовій іiї формі.

За цим твердженням ми можемо узагальнити, що максимально ефективним щодо оптимізації цільової структури капіталу підприємства є метод поєднаного ефекту одночасного росту рентабельності власного капіталу та забезпечення фінансової стійкості, який має можливість динамічної варіативності застосування за різних умов поелементного формування цільової структури капіталу. 


\section{Berezianko Tamara}

\section{5. Висновки}

Результати дослідження підходів до оптимізації структури капіталу підприємств та іiі впливу на рівень фінансової стійкості, свідчать про те, що правильно підібрана за складом, величиною та майновим втіленням структура капіталу підприємств є забезпеченням фінансової стабільності розвитку підприємства в сучасних умовах господарювання. Отже, проведене дало підстави зробити такі висновки:

1. У ході аналізу підходів до оцінки фінансового важеля (основи підвищення рентабельності власного капіталу за рахунок залучення підприємством запозичених) виявлено, що не існує єдиної методики розрахунку даного показника, тобто ефекту фінансового важеля, навіть за єдиною європейською концепцією. Авторська позиція з цього питання полягає у виборі розрахунку ефекту фінансового важеля із використанням показників економічної рентабельності активів та середньої розрахункової ставки відсотків за кредит.

2. При розрахунку економічної рентабельності активів автором обгрунтовано, що середня вартість активів повинна визначатись через систематизацію в моментний динамічний ряд, згідно систематизації показників у часі у вигляді рядів динаміки. У такий спосіб розрахована середня вартість активів дає можливість оцінки економічної рентабельності активів 3 максимальним врахуванням фіксації моментів спостережень вартості активів, що забезпечує більш точну оцінку варіативності цієї вартості.

3.3 метою більш точного визначення диференціалу ефекту фінансового важеля доведено, що середня розрахункова відсоткова ставка за кредит повинна розраховуватись як середня арифметична зважена, в якій значення ознак представлені розміром відсоткової ставки окремих кредитів підприємства, а частоти - сумами окремих залучених підприємством за звітний період кредитів.

4. Доведено, що вибір підприємством тієї чи іншої структури його капіталу може бути здійснений лише за умови виділення певної критеріальної характеристики оптимальності співвідношення структурних елементів капіталу. При цьому, обгрунтовано доцільність прийняття найбільш змістовним критерієм управління формуванням оптимального цільового співвідношення структурних елементів капіталу одночасне зростання рентабельності сукупного власного капіталу та забезпечення фінансової стійкості підприємства. За обраними критеріями отримано новий метод оптимізації цільової структури капіталу - метод поєднаного ефекту. 


\section{Список літератури:}

1. Белолипецкий В. Г. Финансы фирмы: Курс лекций / Под ред. И. П. Мерзлякова. - М.: ИНФРА-М, 1999. - 298 с.

2. Бланк И. А. Управление формированием капитала / И. А. Бланк. - К.: Ника-Центр, 2000. - 512 с.

3. Бочаров В. В. Финансовый анализ / В. В. Бочаров. - СПб: Питер, 2001. $-240 \mathrm{c}$.

4. Вашків П. Г. Теорія статистики: навч. посіб. / П. Г. Вашків, П. І. Пастер, В. П. Сторожук, Є. І. Ткач. - К.: Либідь, 2001. - 320 с.

5. Крейнина М.Н. Финансовый менеджмент: учебн. пособие / М. Н. Крейнина. - М.: Изд-во «Дело и Сервис», 1998. - 304 с.

6. Лапішко М. Л. Основи фінансово-статистичного аналізу економічних процесів / М. Л. Лапішко. - Львів: Світ, 1995. - 328 с.

7. Рясних Є. Г. Основи фінансового менеджменту: навч. посібник / Є. Г. Рясних. - К.: Скарби, 2003. -238 с.

8. Финансовый менеджмент: теория и практика: учебник / Под. ред. Е. С. Стояновой. - 4-е изд., перераб. и доп. - М.: Изд-во «Перспе6ктива», 1999. -656 c.

9. Финансовый менеджмент: учебник для вузов / Г. Б. Поляк, И. А. Акодис, Т. А. Краева и др.; Под ред. проф. Г. Б. Поляка. - М.: Финансы, ЮНИТИ, 1997. $-518 \mathrm{c}$.

10. Шегда А. В. Менеджмент: навч. посібник / А. В. Шегда. - К.: Знання, KOO, 2002. $-583 \mathrm{c}$.

\section{References:}

1. Belolipetskiy V. G. (1999) Finansyi firmyi [Finance of firm]. Moscow: INFRA-M. (in Russian)

2. Blank I. A. (2000) Upravlenie formirovaniem kapitala [Management of formation of capital]. Kiev: Nika-Tsentr. (in Ukrainian)

3. Bocharov V. V. (2001) Finansovyiy analiz [The financial analysis]. St. Petersburg: Piter. (in Russian)

4. Vashkiv P. H., Paster P. I., Storozhuk V. P., Tkach Ye. I. (2001) Teoriia statystyky [Theory of Statistics]. Kiev: Lybid. (in Ukrainian)

5. Kreynina M. N. (1998) Finansovyiy menedzhment [Financial management]. Moscow: Izd-vo "Delo i Servis". (in Russian)

6. Lapishko M. L. Osnovy finansovo-statystychnoho analizu ekonomichnykh protsesiv [Fundamentals of financial and statistical analysis of economic processes]. - Lviv: Svit. (in Ukrainian)

7. Riasnykh Ye. H. (2003) Osnovy finansovoho menedzhmentu [Fundamentals of financial management]. Khmelnytskyi: Skarby. (in Ukrainian)

8. Stoyanova E. S. (1999) Finansovyiy menedzhment: teoriya i praktika [Financial management: theory and practice]. Moscow: Izd-vo "Perspektiva". (in Russian)

9. Polyak G. B., Akodis I. A., Kraeva T. A. Finansovyiy menedzhment [Financial management]. Moscow: Finansyi, YuNITI. (in Russian).

10. Shehda A. V. (2002) Menedzhment [Management]. Kiev: Znannia, KOO. (in Ukrainian) 